\title{
Legal Ethics, Rules of Conduct and the Moral Compass - Considerations from a Law Student's Perspective
}

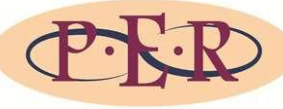

Author

Christoffel Hendrik van Zyl IV \& Jo-Mari Visser

\section{Affiliation}

University of the Free State, South Africa.

Email chris.h.vanzyl@gmail.com visserjm@ufs.ac.za

Date published 15 May 2016

\section{Editor Prof C Rautenbach}

How to cite this article

Van Zyl CH IV and Visser J "Legal Ethics, Rules of Conduct and the Moral Compass -

Considerations from a Law

Student's Perspective" PER /

PELJ 2016(19) - DOI

http://dx.doi.org/10.17159/1727-

3781/2016/v19i0a795

\section{Copyright}

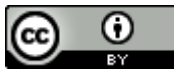

This work is licensed under a Creative Commons Attribution 4.0 International License.

DOI

http://dx.doi.org/10.17159/17273781/2016/v19i0a795

\begin{abstract}
When young law graduates enter the legal profession they will undoubtedly be exposed to difficult situations that will demand of them to make difficult decisions, often having to balance conflicting systems of belief and ideas on what ethical behaviour entails. Legal ethics training in law faculties the world over often neglects teaching aspects of morality to focus on reviews of rules of professional legal conduct. This article argues that if legal education is to adequately prepare law graduates for legal practice, it must offer more than reviews of these codes of conduct. To properly assist law students in avoiding pitfalls which may lead to disciplinary action, they must be taught to appropriately use their moral compasses.

This narrative aims to show that the metaphorical moral compass, with the cardinal virtues as possible main points, may serve as the crucial and underlying guide in the avoidance of the pitfalls which may result in a person being struck from the roll, but more than that, that it may aid in the pursuit of personal dreams or goals. The article contributes to the literature on legal ethics by foregrounding the virtues that pertain to sound conduct in a lawyer, as opposed to the rules and codes, in the hope that this may help legal practitioners to decide on what is right and what is wrong.
\end{abstract}

\section{Keywords}

Legal ethics; morality; law students; professional conduct; moral compass; legal education. 


\begin{abstract}
... law office conversations are almost always moral conversations. This is so because they involve law; law is a claim which people make on one another a claim resting on obligation, a moral claim - and one upon which they may seek the sanction and coercion of the state. In this derivative sense, a conversation about rights and duties is by definition a moral conversation. ${ }^{1}$
\end{abstract}

\title{
1 Introduction
}

In recent years, public perception of the legal profession in South Africa has been tainted by media reports about professional misconduct. ${ }^{2}$ Where instances of misconduct are verified in court, the legal practitioners involved can be (and often are) removed from the roll of attorneys or advocates. Such removal is evidence of the fact that the court no longer considers these practitioners "fit and proper", or of sufficient moral fibre to serve in the legal system.

Being fit and proper is of the utmost importance to legal practitioners. Not only is it a fundamental statutory requirement for admittance, but it is also indispensable in avoiding disbarment from the esteemed and honourable profession of the law. ${ }^{3}$ Since no legislative or regulatory framework exists to describe exactly what it is to be fit and proper, and since it is clearly the cornerstone upon which entry to legal practice rests, law students approaching the dawn of their careers may rightly ponder the questions: "What is meant by 'fit and proper'?" or "How do I avoid being struck from the roll?" A good place to look for the answers to these questions is the professional codes of conduct, for example. Apart from this external source, a student may also answer these questions internally; that is, with reference to his own moral compass.

While conceding that rules of professional conduct are important to legal practice, Schiltz ${ }^{4}$ warns that this importance should not be overestimated. While legal practitioners make daily decisions about what ethical conduct is and whether or not they will conduct themselves in an ethical manner, formal rules of conduct have very little to do with this decision-making

* Christoffel Hendrik van Zyl IV LLB (summa cum laude) (UFS). Co-wrote article when he was a final year student at the UFS. E-mail: chris.h.vanzyl@gmail.com.

** Jo-Marí Visser. BSc BMedSc Honours (UFS), MSc Med Crim (UP), LLB LLD (UFS). Senior lecturer in the Department of Public Law, University of the Free State, South Africa. E-mail: visserjm@ufs.ac.za.

$1 \quad$ Shaffer 1979 Notre Dame Law 232.

2 See Waldner City Press 2; Venter Star 4; Peters Daily News 6; Maphumulo Sunday Independent 1. For a thorough discussion of selected cases, see Slabbert 2011 PELJ 211-221.

3 See ss 3 and 7(1)(d) of the Admission of Advocates Act 74 of 1964 (as amended) and ss 15 and 22(1)(d) of the Attorneys Act 53 of 1979.

4 Schiltz 1998 Minn L Rev 713. 
process. Rules of professional conduct do not define ethical legal practice, which requires much more than mere rule compliance. ${ }^{5}$

Slabbert ${ }^{6}$ writes that in South Africa it is commonly accepted that to be fit and proper, a legal practitioner must exhibit integrity, reliability and honesty. Yet Slabbert ${ }^{7}$ also believes that formal legal education does not adequately prepare students for the moral challenges of the legal profession. Teaching legal ethics properly at university may very well be one way of helping to ensure that a law student, as a prospective lawyer, understands and adheres to the requirements of being a fit and proper person. Unless they decide to become lecturers, law students will be exposed to further training in legal ethical practice when doing their clerkship or pupillage. The vital role mentors play at this stage cannot be negated. Nevertheless, legal education plays an essential role in teaching legal ethics and how students perceive themselves in society. ${ }^{8}$ The law lecturer is an important link in attempting to ensure morally upright legal practitioners.

This article argues that if legal education in law faculties, as one of the important role-players in forming sound lawyers, is to succeed in producing legal graduates of strong moral fibre and who are fit for practice, it must offer more than reviews of codes of conduct. To properly assist law students in avoiding pitfalls which may lead to disciplinary action, they must be informed about how their internal moral compasses can help them do so. ${ }^{9}$

Bearing these issues in mind, what follows is in many ways a narrative of a particular (perhaps peculiar) law student's ${ }^{10}$ quest to discover how the moral compass relates to legal ethics and what the basics of such a compass ought to be, especially within the context of legal practice. This narrative aims to show that the metaphorical moral compass, with the cardinal virtues as possible main points, may serve as the crucial guide in the avoidance of the pitfalls which may result in a person being struck from the roll, but more than that, it may aid in the pursuit of personal dreams or goals. ${ }^{11}$ The article contributes to the literature on legal ethics by considering the virtues as

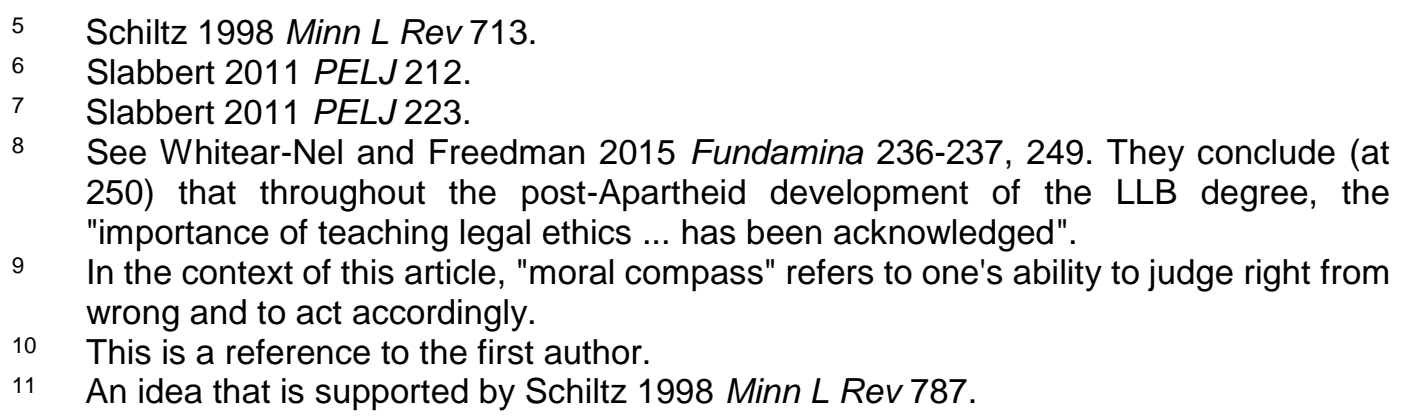

9 In the context of this article, "moral compass" refers to one's ability to judge right from wrong and to act accordingly.

10 This is a reference to the first author.

11 An idea that is supported by Schiltz 1998 Minn L Rev 787. 
supplementary to the rules and codes, which may help legal practitioners in deciding on what is right and what is wrong.

To demonstrate these goals, some of the possible pitfalls will be considered. Then legal ethics and its relation with the moral compass will be described, and this will be followed by a discussion on the meaning of the moral compass and the value of including it in a legal education curriculum.

\section{Possible pitfalls that may threaten the "fit and proper" status}

Although an applicant bears the burden of proof to show that he is "fit and proper" to be admitted as an attorney or advocate, the final decision lies with the court and is essentially discretionary. A senior in the profession interviews the applicant and then testifies whether the applicant is a "fit and proper" person or not. The court finally confirms the senior's discretionary value-judgement, but judges may also ask additional questions to their satisfaction. ${ }^{12}$

But what are some of the reasons why persons are struck from the roll for no longer being "fit and proper" persons? Perhaps more importantly, how does one avoid them? Before we consider the how, note must be taken of the what. Slabbert ${ }^{13}$ offers the following as possible reasons why lawyers do not act as fit and proper persons:

a) The adversarial system in which there are two opposing parties. This system has the potential to sometimes pressure a lawyer to place his client's interest not only ahead of the interest of the adversary but ultimately ahead of the interests of justice. ${ }^{14}$

b) Increased competition at a professional level and among law firms who sacrifice morality "... in order to take and win more cases" than the opposition.

c) Legal education at universities that does not prepare prospective lawyers for the moral challenges of the legal profession.

Slabbert 2011 PELJ 218.

Slabbert 2011 PELJ 221-223.

See Slabbert 2011 PELJ 221 citing (at fn 53) Eshete "Does a Lawyer's Character Matter?" 272. 
d) The general lawlessness which is prevalent and perceptible in society. Moral bonds are relaxed and persons either lack or do not use their internal moral compasses.

General lawlessness and the relaxation of moral bonds emphasise why focus on the moral compass is important and necessary for law students and lawyers. ${ }^{15}$ In everyday legal practice, attorneys and advocates are expected to make difficult decisions in often difficult circumstances. This process frequently requires legal practitioners to balance conflicting systems of belief. ${ }^{16}$ In a country as diverse in culture, beliefs and customs as South Africa, decisions on what is moral and immoral can potentially be complicated and uncertain. While considerations of what is "right" and "wrong" might share some common ground, the question of what is moral or immoral conduct in all challenging legal circumstances can become difficult. The legal profession, in order to address the potential for uncertainty in legal ethical disputes, strives to maintain confidence and nobility, and aspires to protect the public from unethical and unprofessional lawyers. To assist lawyers in avoiding ethical pitfalls and ambiguity in deciding on what is right and wrong, the legal profession has developed a system of professional codes and rules of conduct by which its members must abide. ${ }^{17}$ But while these codes and rules of conduct establish wide parameters of acceptable and unacceptable conduct, they do not inform on fit and proper character and moral formation. ${ }^{18}$

Rothenberg ${ }^{19}$ argues that very difficult ethical issues in legal practice arise due to the tensions inherent in legal practitioners' competing responsibilities towards their clients, the legal system and the quality of justice. Tertiary legal training, it is argued here, should empower students with foundational standards and skills beyond codes of conduct to assist them in exploring these issues in terms of what is right and wrong, instead of what is acceptable to win a case.

15 Benson 2000 UBC L Rev 519 notes: "A deeper ground for moral education is both necessary to citizenship and largely missing from contemporary education of all sorts including the law. What now stands in the place of moral education is a series of disconnected concepts (e.g. 'tolerance,' 'equality,' 'self-esteem,' and 'rights') that are themselves obscured by a loss of historic understanding of such concepts as 'virtue' and the rise of a superficial language of 'values'". (Our emphasis).

16 Rothenberg 2009 U Tol L Rev 412.

17 For example: the Rules for Professional Conduct of the General Council of the Bar for advocates; the rules for conduct for attorneys by the South African Law Society; the Code of Conduct for members of the National Prosecuting Authority, etc.

18 Rothenberg 2009 U Tol L Rev 412.

19 Rothenberg 2009 U Tol L Rev 412-413. 


\section{$3 \quad$ Legal ethics and the moral compass}

Legal ethics plays an important part in ensuring that the conduct of lawyers meets the requirement of a fit and proper person and protects the public from unprofessional and unethical lawyers. Legal ethics should also play a significant role in guiding the lawyer to avoid the pitfalls or possible reasons (as listed above) for not being a fit and proper person. If legal ethics plays a role in helping a person to be fit and proper, what role does a moral compass have? In order to explore the relation between legal ethics and the moral compass, we need to explore what each is.

\subsection{Legal ethics briefly explored}

Legal ethics falls within the broader realm of ethics, which is the "the philosophical study of morality..."20 or "[a] set of moral principles, esp. those of a specified religion, school of thought, etc." 21 Legal ethics may be defined as:

The minimum standards of appropriate conduct within the legal profession, involving the duties that its members owe one another, their clients and the courts ... [t]he written regulations governing those duties. ${ }^{22}$

or

The code of conduct among lawyers which governs their moral and professional duties toward one another, toward their clients, and toward the courts. ${ }^{23}$

The term legal ethics has a narrow and a broad meaning. Narrowly, it refers to "... the system of professional regulations governing the conduct of lawyers". ${ }^{24}$ However, legal ethics is more than the mere rules or regulations of the legal profession, since it also connotes "the moral principles" of the legal profession. Broadly speaking, therefore, legal ethics is a specific and singular case of ethics in general. ${ }^{25}$

Why then does a lawyer need to use his moral compass if legal ethics, which includes the moral principles of the legal profession, can serve as a guide to avoid the pitfalls of being struck from the roll? According to Kiefel, ${ }^{26}$ a

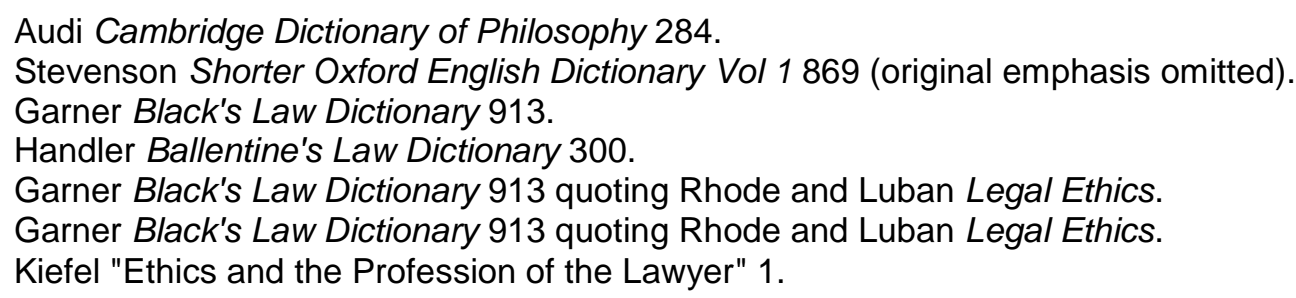


Justice of the High Court of Australia, the "Rules of Professional Conduct and Practice" do provide lawyers with guidance and standards of conduct; however,

[t]hey cannot provide the answer to every ethical and moral question which a lawyer may face; for that a lawyer needs his or her own moral compass.

Bahnsen ${ }^{27}$ writes that "all of life is ethical ...". Hence, a lawyer will always use his moral compass. Where legal ethics, especially in the form of a narrow set of rules, is silent or perhaps inconclusive on the issues facing the lawyer, the practitioner uses his moral compass to decide what is right and just. In other words, to remain fit and proper when answering those "ethical and moral questions" a lawyer needs to use his moral compass.

A moral compass is also more readily accessible where immediate decisions are needed to resolve the ethical choices one faces each day. This does not mean that a lawyer "grabs" his moral compass only when other sources are silent or ambiguous. A moral compass is internal; it is something its possessor "carries" with him everywhere. Consequently, whenever a decision or judgement is made, the internal moral compass is used. Whether the decision made follows the direction indicated by the moral compass or not is another question. Whenever a decision or judgement is made and action is taken accordingly, one must be able to defend one's decision and subsequent action.

A moral compass, in relation to legal ethics, is also necessary in that it signifies certain qualities or traits of character which will not only keep a lawyer or a law student fit and proper for the mere sake of being fit and proper, but also for the sake of helping him to pursue his dreams or goals whether of being a selfless servant of the public, an advocate, a revered Constitutional Court judge, a Member of Parliament, an academic or a lecturer.

\subsubsection{Moral compass briefly explored}

One's moral compass has been briefly shown to have a viable and necessary interaction with legal ethics and the legal profession. But what is it? The metaphorical moral compass may be defined as "a natural feeling that makes people know what is right and wrong and how they should behave..." 28 or as a term "[u]sed in reference to a person's ability to judge

\footnotetext{
27 Bahnsen By This Standard 21.

28 Cambridge Dictionaries Online date unknown http://bit.ly/1 Nwd7Vw.
} 
what is right and wrong and act accordingly..."29 The definition of a "conscience", which is a synonym of the moral compass," is also instructive in describing this metaphor. "Conscience" is "[a] moral sense of right and wrong..." 30 or "the sense of right and wrong that governs a person's thoughts and actions." 31 "Conscience" and the metaphorical moral compass are closely related in that both involve a sense or feeling of what is right and wrong. This "moral sense" is "the ability to distinguish between right and wrong, especially as a faculty of the human mind." 32 The metaphorical moral compass may therefore be described here to mean the ability, as developed and formed, of a lawyer or a law student to judge or decide what is right and wrong and then to act according to his judgement or decision, knowing that he should be able to defend his judgement or decision.

Virtues aid in deciding between right and wrong. Hence they are important components of the moral compass. An honest lawyer will not lie to the court; one with integrity will not overcharge clients; a punctual student will not be late for lectures, etc. It is imperative that one should develop virtues, as they will contribute to rendering one a fit and proper person. These virtues will also help one to accomplish ones dreams and goals. ${ }^{33}$

Virtues important to the "fit and proper" requirement for admission to legal practice include the following: integrity and being honest, being responsible and being courteous. To start this quest for virtues, which comprise an important part of one's moral compass, we turn to the classical labelling of the principal or fundamental virtues: the cardinal virtues.

\section{The cardinal virtues - the main four points of your compass}

Once again using the metaphor of a moral compass, it is suggested here that the cardinal virtues may serve as the four main points (North, East, South and West) of one's moral compass. The cardinal virtues provide a starting point, a skeleton which may be fleshed out with virtues which one considers to be of more personal or professional relevance and importance than others. Individuals are unique, and in South Africa's vibrant society people come from diverse backgrounds, cultures and religions. Hence, each unique person's moral compass will have "features" or "characteristics"

\footnotetext{
Oxford Dictionaries date unknown http://bit.ly/1reSvY1.

Stevenson Shorter Oxford English Dictionary - Vol 1494.

Summers and Holmes Collins English Dictionary 244.

Stevenson Shorter Oxford English Dictionary - Vol 11835.

See in this regard Schiltz 1998 Minn L Rev 787.
} 
particular to that person. Regardless of the unique features, there ought to be some indispensable basics in the moral compass of a person. In this narrative the cardinal virtues are suggested as such basic building blocks.

\subsection{What is a virtue?}

A virtue may be defined as "the quality or practice of moral excellence or righteousness". ${ }^{34}$ According to Blackburn ${ }^{35}$

[a] virtue is a trait of character that is to be admired: one rendering its possessor better, either morally, or intellectually, or in the conduct of specific affairs.

Benson ${ }^{36}$ notes that "... 'virtues' are objective moral norms that are both shared and personal".

For the purposes of this article, a virtue may be described as an objective moral norm or an internal quality or trait of character which influences or directs the ability to judge between right and wrong and to act accordingly.

The four virtues (wisdom, fortitude, temperance and justice) were grouped together as the cardinal virtues by St. Thomas Aquinas. ${ }^{37}$ However, their importance can be traced to the writers of the classical period: Socrates, Plato and Aristotle. ${ }^{38}$ These four virtues were termed "cardinal", a term which comes from the Latin word meaning "the hinge of the door." ${ }^{39}$ All other virtues are therefore said to pivot or "hinge" on the four principal or fundamental virtues. Apart from these four moral or "natural virtues" there are also three "inspired" or theological virtues: faith, hope and charity. ${ }^{40}$

Virtues are shared because we can all know what they are; that is, they are objective. ${ }^{41}$ Virtues are also personal, since one can assess oneself personally in relation to a particular virtue. ${ }^{42}$ For example, when assessing oneself in relation to temperance one may determine that one's overindulgence is a lack of temperance. Related to this is the concept that each of the cardinal virtues, and any other virtue, is a via media or middle between

\footnotetext{
34 Summers and Holmes Collins English Dictionary 1350; also see Stevenson Shorter Oxford English Dictionary - Vol 23538.

35 Blackburn Oxford Dictionary of Philosophy 381 (my emphasis).

36 Benson 2008 JJS 16 (author's original emphasis omitted).

37 Benson 2008 JJS 17.

38 Benson 2008 JJS 17; also see Van Zyl 2010 Fundamina 528-529.

39 See Benson 2008 JJS 17; and Lewis Mere Christianity 76.

40 Benson 2008 JJS 11; 17-18; and Lewis Mere Christianity 76.

41 Benson 2008 JJS 16.

42 Benson 2008 JJS 16.
} 
two extremes. ${ }^{43}$ For example, temperance is the mean or middle way between unfounded abstinence ${ }^{44}$ and over-indulgence. Consequently, in developing or pursuing the perfection of a virtue, one assesses oneself to determine where one is in relation to that middle way, and then one grows toward that middle way.

Before a brief introductory discussion of each of the cardinal virtues, a caution by Lewis about the difference between a virtuous act and a virtuous person must be noted. ${ }^{45} \mathrm{He}$ points out that the distinction is important because one might get the wrong idea that it does not matter how or why one performed a virtuous act, only that one has done it. These virtuous acts

... done for the wrong reason do not help to build the internal quality or character called a "'virtue,"' and it is this quality or character that really matters. ${ }^{46}$

\subsection{Wisdom (prudence)}

Wisdom (rendered in Latin as sapientia by Cicero) is not merely the accumulation of theoretical knowledge, but also includes "practical wisdom" or prudence. ${ }^{47}$ It was Aristotle who introduced this distinction between theoretical wisdom (sophia) and practical wisdom (phronesis). ${ }^{48}$ In fact, Lewis ${ }^{49}$ does not even mention "wisdom." He refers only to "prudence", which he says is "practical common sense".

For a lawyer using this point of his moral compass, wisdom entails two things. Firstly, wisdom means a sound "theoretical knowledge" of the law and its workings and an understanding of legal ethics. Secondly, wisdom (or prudence) requires a lawyer to apply "practical common sense" in his dealings with the law, the courts, colleagues, clients and society. He must heed the proverb that "the prudent man looketh well to his going". ${ }^{50}$ The prudent man does not speed down the road of life (or any other road); he observes his way with "practical common sense". Prudence therefore navigates the mean between impulsiveness and over-cautiousness and

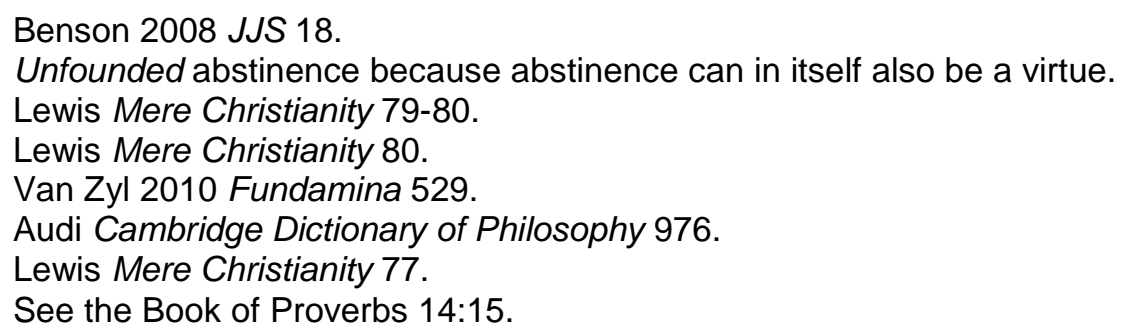


performs the special function of assisting in the choice "between good and evil". 51

\subsection{Courage (fortitude)}

According to Lewis, ${ }^{52}$ fortitude includes two kinds of courage. The first is probably the one that immediately comes to mind when one hears the word courage: bravery, lack of fear, or the courage that faces danger. ${ }^{53}$ The second type of courage is the type "that 'sticks it' under pain". 54 "Guts" or "perseverance" are good modern renderings. Cicero points out that the virtue of "fortitude (fortitudo) comes to the fore in dealing with toil and trouble..."55

A courageous lawyer or law student is therefore one who perseveres or sticks at it when he has to prepare for a case or study for a test and when he has to toil at a difficult legal problem. A courageous lawyer is one who is not afraid to do all that he can to ensure that justice prevails and is accessible. He boldly pursues his goals and dreams. A courageous lawyer is one who, in the face of losing much profit, follows the advice of former president of the United States of America and lawyer Abraham Lincoln:

Discourage litigation. Persuade your neighbors [sic] to compromise whenever you can. Point out to them how the nominal winner is often a real loser - in fees, expenses, and waste of time. As a peacemaker the lawyer has a superior opportunity of being a good man. There will still be business enough. ${ }^{56}$

Courage is also connected with the other virtues, in that growing towards the middle way or developing a virtue takes courage (guts or perseverance). It takes courage to pursue justice, to practise moderation or to acquire knowledge.

\subsection{Temperance (self-restraint or moderation)}

Lewis $^{57}$ emphasises that temperance does not mean teetotalism and neither does it refer just to alcohol but to all pleasures. Temperance also does not mean unfounded abstinence, "... but going the right length and no further". ${ }^{58}$ In other words being moderate and not extreme. Temperance

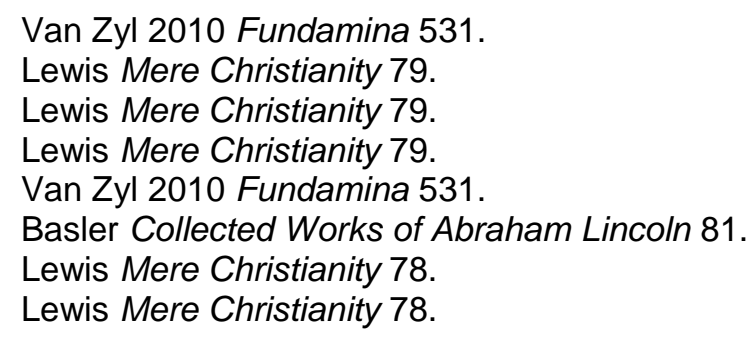


does not mean that pleasure or the delights of life are alien to the one who pursues the perfection of or develops this virtue, but rather that he exploits pleasure to his benefit and not to his harm.

By way of example, temperance for a law student would mean that he moderates himself in the partaking of red wine in such a manner that his driving of a motor vehicle will remain within the bounds of the law or that he will be in possession of all his mental faculties for tomorrow's test. In exercising temperance, a lawyer or law student does so courageously in the face of tempting over-indulgence in pleasure, in prudent consideration of the possible adverse consequences of such over-indulgent pleasure, and ultimately in pursuit of justice.

\subsection{Justice}

Finally we come to the virtue which a lawyer may rightly see as the most important virtue in his profession: justice.

Cicero referred to justice as "the intention to give to each what he deserves", and this was echoed by St. Thomas Aquinas. ${ }^{59}$ Justice, apart from what we associate with courts of law, can also be described as "fairness". ${ }^{60}$ Ever since Aristotle's time, "... justice has commonly been identified both with obeying the law and with treating everyone with fairness". ${ }^{61}$ Justice, as a pivotal virtue, includes virtues such as honesty, truthfulness and keeping promises. ${ }^{62}$

Although some writers view wisdom as the primary cardinal virtue, justice was seen by Cicero "...as a virtue underlying all human relationships on the basis of shared interests and the need to give to each his own (suum cuique tribuere)". ${ }^{63}$ For a lawyer the virtue of justice may very well be the underlying virtue. A lawyer may strive to be just or fair in his relationship and interaction with his clients, the court, the public and colleagues. But more than being a man pursuing the perfection of or developing the virtue of justice, a lawyer also seeks justice or fair treatment for others, whether it be for the alleged victim or for the alleged perpetrator of some crime or delict. According to Van Zy| ${ }^{64}$ the virtue of justice

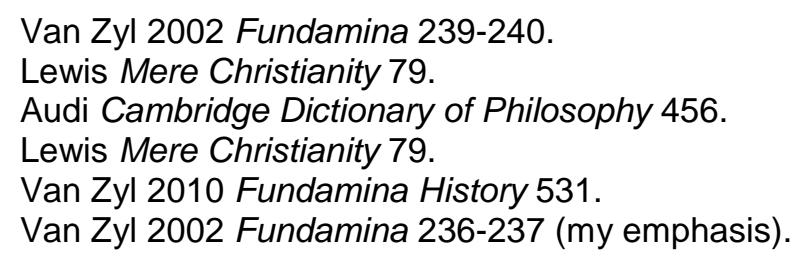


... occupies primacy of position [in the judicial sphere]. It is the essential function of a judge to do justice between man and man. In doing so, he must apply his knowledge and insight with wisdom and prudence. The need for impartiality and independence, however, requires that he acts with courage and fearlessness. But then again, he cannot exercise his functions like a bull in a China shop. He must do so with temperance and self-control. In this way he may be assured that justice will be done in a fair and reasonable way, as required by the community which he serves.

Although justice may play a leading role, Cicero points out that each cardinal virtue still has its special function to perform, and justice's function is to accord to each his own. ${ }^{65}$ The above quotation shows how justice relates to the virtues of courage, wisdom and temperance to lead ultimately result to just decision.

Finally, Cicero pronounced that by applying the cardinal virtues "...one could achieve the 'greatest good' (summum bonum) which would be reflected by the leading of a virtuous, moral and ethically correct life". ${ }^{66}$ These pivotal virtues provide a framework which will foster the development of other virtues relevant and important to the individual and his profession or occupation. Examples of such other virtues include being honest, responsible, merciful, deferent, committed, dependable, diligent, persuasive, thorough, punctual, tolerant and truthful.

\section{Conclusion}

When one observes that all these "fallen" lawyers were once regarded as fit and proper persons and in all likelihood were familiar with the content of legal ethics, it nurtures the realisation that a lawyer cannot rely on mere rules and codes alone to be a fit and proper person. This person has and must use his moral compass. This realisation should encourage students to take up their moral and social responsibility to use their internal moral compasses as an important means to be a fit and proper legal servant of the public. However, a moral compass must have moral content. Developing and pursuing the perfection of the cardinal virtues and of other virtues improves and directs one's moral compass, which in turn helps ensure that one remains a fit and proper person. However, for the law student who desires to be better than the minimum requirement, the pursuit of these and other virtues supports him in realising his dreams or goals of being a selfless public servant, a revered judge or an efficient prosecutor.

\footnotetext{
65 Van Zyl 2010 Fundamina 531-532.

66 Van Zyl 2010 Fundamina 529.
} 
The moral compass should not be seen as an idealistic ambition, but as a useful tool for law students and lecturers alike in the face of an increasing lack of moral fibre in the legal profession and society at large. Benson ${ }^{67}$ argues that "the language of virtues" should be (re-)built into courses at schools and universities along with the narratives "that illustrate [virtues] and their relationship to the happiness and proper freedom that is integral to human flourishing". Benson ${ }^{68}$ also points out that if we are to achieve "an educational renaissance" we must start with the teachers, because they are the ones who have been deprived of "the language of virtues", which is vital to reform education. While it is certainly not the province of lecturers to configure a moral compass from scratch in law students (that may well be the primary job of their parents, family, schools and religion) it has arguably become necessary for lecturers to impress upon students the vital place of a moral compass in the legal profession and its necessity for a just and accessible legal system. This is done in addition to conveying the import of codes of ethics in the relevant courses.

Inevitably the law lecturer teaches students who each have their own worldviews based on either religious or non-religious beliefs, which worldviews inform their moral compasses. ${ }^{69}$ Each of these students from diverse backgrounds makes and will have to make moral choices. In the light of this diversity of beliefs, the lecturer might be "prudent" to require reflection essays or to facilitate discussions and debates on topics such as "your moral compass", "fit and proper", "what are legal virtues" and "cardinal virtues". Such discussions and debates would not only expose students to the diversity of beliefs in South African society but would also be an opportunity to foster respect for other persons, despite their being different from oneself. While students have the freedom to develop their moral compasses in line with their own beliefs, the cardinal virtues remain possible essential points on the moral compass. There are, of course, also virtues

67 Benson 2008 JJS 20. This is opposite to the problematic "language of values" prevalent in moral language today, which confusion Benson identifies and argues against. Benson 2000 UBC L Rev 532-533 writes that "[i]t would be better that children, the citizens of tomorrow, be taught something of 'justice' and 'prudence' ..." than to be taught about subjective and "... necessarily ambiguous 'values'". Ultimately, "how can a student differentiate between what is genuinely good and necessary and what is personal and, perhaps, trivial ..." when "... the axiom of modernity, is that 'you have your values and I have mine."'? (original emphasis).

68 Benson 2008 JJS 21.

69 Benson 2000 UBC L Rev 532 notes that a "...'virtues based' curriculum ought not to conflict with religious or non-religious liberal beliefs and ought to provide a much richer ground for citizenship and public education than the current 'soft relativism' of 'valuesbased' education which amounts to little more than a mélange of half-formed sentiments". 
which are more particular to the legal profession, eg honesty, integrity and justice, or to the law student, like studiousness and diligence. On these and other virtues the lecturer may focus as "legal virtues".

Gilbert K Chesterton ${ }^{70}$ declared in 1901: "The act of defending any of the cardinal virtues has to-day all the exhilaration of a vice." Hopefully, lecturers will experience this thrill when they emphasise and facilitate discussions on the necessity of being guided by one's moral compass in life and in law.

\section{Bibliography}

\section{Literature}

Audi Cambridge Dictionary of Philosophy

Audi R (ed) The Cambridge Dictionary of Philosophy $2^{\text {nd }}$ ed (Cambridge University Press Cambridge 1999)

Bahnsen By This Standard

Bahnsen G By This Standard (Institute for Christian Economics Tyler 1991)

Basler Collected Works of Abraham Lincoln

Basler RP (ed) The Collected Works of Abraham Lincoln - Volume II (Rutgers University Press New Brunswick 1953)

Benson 2000 UBC L Rev

Benson IT "Notes Towards a (Re)Definition of the 'Secular"' 2000 UBC $L$ Rev 519-549

Benson 2008 JJS

Benson IT "Do 'Values' Mean Anything at All? Implications for Law, Education and Society" 2008 JJS 1-22

Blackburn Oxford Dictionary of Philosophy

Blackburn S Oxford Dictionary of Philosophy $2^{\text {nd }}$ ed (Oxford University Press Oxford 2008)

Chesterton Defendant

Chesterton GK The GK Chesterton Collection: The Defendant (Catholic Way Publishing London 2014)

70 Chesterton Defendant 2204 
Eshete "Does a Lawyer's Character Matter?"

Eshete A "Does a Lawyer's Character Matter?" in Luban D (ed) The Good Lawyers' Roles and Lawyers' Ethics (Rowman and Allanheld Totowa 1984) 270-285

Garner Black's Law Dictionary

Garner BA (ed) Black's Law Dictionary $8^{\text {th }}$ ed (Thomson West St Paul 2004)

Handler Ballentine's Law Dictionary

Handler JG (ed) Ballentine's Law Dictionary: Legal Assistant Edition (Delmar Albany 1994)

Kiefel "Ethics and the Profession of the Lawyer"

Kiefel S "Ethics and the Profession of the Lawyer" Unpublished contribution delivered at the Queensland Law Society's The Vincents' 48 th Annual Symposium (26-27 March 2010 Brisbane)

Lewis Mere Christianity

Lewis CS Mere Christianity (Collins London 2012)

Maphumulo Sunday Independent

Maphumulo S "NPA Official's Office Raided by His Own Colleagues" Sunday Independent (31 August 2014) 1

Peters Daily News

Peters S "Lawyer in Trouble Over RAF Payout" Daily News (12 February 2014) 6

Rhode and Luban Legal Ethics

Rhode DL and Luban D Legal Ethics (Foundation Westbury 1992)

Rothenberg 2009 U Tol L Rev

Rothenberg $\mathrm{KH}$ "Recalibrating the Moral Compass: Expanding 'Thinking Like a Lawyer' into 'Thinking Like a Leader'" 2009 U Tol L Rev 411-420

Schiltz 1998 Minn L Rev

Schiltz PJ "Legal Ethics in Decline: The Elite Law Firm, the Elite Law School, and the Moral Formation of the Novice Attorney" 1998 Minn L Rev 705-792

Shaffer 1979 Notre Dame Law

Shaffer TL "The Practice of Law as Moral Discourse" 1979 Notre Dame Law 231-253 
Slabbert 2011 PELJ

Slabbert M "The Requirement of Being a 'Fit and Proper' Person for the Legal Profession" 2011 PELJ 209-231

Stevenson Shorter Oxford English Dictionary

Stevenson A (ed) Shorter Oxford English Dictionary - Vol 1 and $26^{\text {th }}$ ed (Oxford University Press Oxford 2007)

Summers and Holmes Collins English Dictionary

Summer E and Holmes A (eds) Collins English Dictionary and Thesaurus $3^{\text {rd }}$ ed (HarperCollins Glasgow 2004)

Van Zyl 2002 Fundamina

Van Zyl DH "Ancient Values in Modern Context" 2002 Fundamina 234-245

Van Zyl 2010 Fundamina

Van Zyl DH "Ciceronian Virtues and Values in Contextual Perspective" 2010 Fundamina 526-538

Venter Star

Venter Z "Sisulu Attorney is Struck From the Roll" Star (5 August 2013) 4

Waldner City Press

Waldner M "Lawyers Pocket R7bn from RAF" City Press (29 November 2009) 2

Whitear-Nel and Freedman 2015 Fundamina

Whitear-Nel N and Freedman W "Historical Review of the Development of the Post-Apartheid South African LLB Degree - with Particular Reference to Legal Ethics" 2015 Fundamina 234-250

\section{Legislation}

Admission of Advocates Act 74 of 1964

Attorneys Act 53 of 1979

\section{Internet sources}

Cambridge Dictionaries Online date unknown http://bit.ly/1Nwd7Vw Cambridge Dictionaries Online date unknown http://bit.ly/1Nwd7 Vw accessed 9 September 2014 
Oxford Dictionaries date unknown http://bit.ly/1reSvY1

Oxford Dictionaries date unknown http://bit.ly/1reSvY1 accessed 19 August 2014

\section{List of Abbreviations}

PELJ

Minn L Rev

JJS

LCP

Notre Dame Law

U Tol L Rev

UBC L Rev
Potchefstroom Electronic Law Journal

Minnesota Law Review

Journal for Juridical Science

Law and Contemporary Problems

Notre Dame Lawyer

University of Toledo Law Review

University of British Columbia Law Review 